ISSN 1392-3196 / e-ISSN 2335-8947

Zemdirbyste-Agriculture, vol. 103, No. 4 (2016), p. 339-346

DOI 10.13080/z-a.2016.103.043

\title{
Assessment of soil erosion processes as influenced by different land-use systems on hilly rolling landscape of Western Lithuania
}

\author{
Irena KINDERIENE, Danute KARCAUSKIENE \\ Vèžaičiai Branch, Lithuanian Research Centre for Agriculture and Forestry \\ Gargždų 29, Vėžaičiai, Klaipėda distr., Lithuania \\ E-mail: kaltbs@kaltbs.lzi.lt
}

\begin{abstract}
The objective of this study was to estimate long-term effect of different land-use/cover systems on soil erosion processes on the hilly topography of Žemaičiai Upland in Lithuania. The study analyses long-term (18 years) monitoring data from three individual erosion experiments set up on slopes of $7-8^{\circ}, 7-9^{\circ}$ and $9-11^{\circ}$ steepness with installed water and outwash collectors. Six land-use systems were investigated: field crop rotation (F), field crop rotation with the black fallow (FF), erosion-resisting grain-grass (GR), erosion-resisting grass-grain (GS), not fertilized and not used grassland (NG) and fertilized and mown grassland (FG). It was found that soil erosion losses and water runoff volume on the slopes of the arable agricultural land generally depended on the erosionpreventative capabilities of different crops, tillage technology and vegetation cover of slope, soil texture and precipitation characteristics. Torrential rainfall in summer and autumn was the cause of most cases of rainwash and soil loss - 167.8-229 $\mathrm{Mg} \mathrm{ha}^{-1} \mathrm{yr}^{-1}$, which is described as very strong erosion. Climate warming processes (about $0.7^{\circ} \mathrm{C}$ over more than 30 years) and a positive air temperature encouraged snow melting and runoff water flow down of the slope surface, even during the cold period.

Summarized long-term research results suggest that the highest average annual precipitation runoff volume $529 \mathrm{hl} \mathrm{ha}^{-1} \mathrm{yr}^{-1}$ and average annual soil loss $-11.6 \mathrm{Mg} \mathrm{ha}^{-1} \mathrm{yr}^{-1}$ were from bare soil plot in the black fallow land-use system on $9-11^{\circ}$ slope with a larger amount of sand particles, compared with the other experimental soil. Erosionresisting grain-grass and grass-grain land-use systems decreased soil loss compared with black fallow system by on average 5 and 15.5 times, respectively. Effectiveness of soil loss reduction of the not fertilized and not used grassland and fertilized and mown grassland land-use/cover systems with a cover formed of permanent multicomponent plant mixture was $99-100 \%$. High erosion resistance of plants by using suitable land-use systems on the hillslopes markedly reduced soil loss $(r=-0.99, P<0.01, \mathrm{n}=18)$ and runoff volume $(r=-0.607, P<0.01$, $\mathrm{n}=18$ ). Not fertilized and not used and fertilized and mown grassland systems prevented erosion regardless of the location, steepness of the slope and soil texture and increased the stability against erosion by water on the hilly topography of Lithuania.
\end{abstract}

Key words: erosion-preventative systems, hillslopes, long-term experiments, soil loss, water runoff, Žemaičiai Upland.

\section{Introduction}

Soil is one of the most important and most complex natural resources, but current developments (urbanisation, erosion and climate change) increasingly threaten this valuable resource in Europe and worldwide (Morgan, 2006). Erosion process formation events in agricultural lands in European countries were described by authors: Boardman and Poesen (2006) and Bechmann (2012). Natural rich rainfall, slope and soil parameters and incorrect land use are the most important factors for the induction of erosion (Cerdan et al., 2010; Kinderiene, Karcauskiene, 2012). Moreover, soil tillage technology operations strongly influenced surface state in hilly landscapes and caused some erosion risk (Brunner et al., 2008).

Between 1985 and 2005 researchers confirmed that not only erosion was a problem but that runoff and its impacts (muddy floods and pollution of water courses by sediment, phosphate and pesticides) were also problems (Evans, 2010). Verheijen et al. (2009) estimated a limit for tolerable soil erosion rates in Europe of 0.3-1.4 $\mathrm{tha}^{-1}$ $\mathrm{yr}^{-1}$, whereas the actual erosion rates, including all erosion forms, are 3-40 $\mathrm{t} \mathrm{ha}^{-1} \mathrm{yr}^{-1}$ at the field scale. Panagos et al. (2015) have estimated the mean soil loss rate in the European Union's erosion-prone lands $-2.46 \mathrm{t} \mathrm{ha}^{-1} \mathrm{yr}^{-1}$. The soil loss rates of about $76 \%$ of the total European land area were less than $2 \mathrm{t} \mathrm{ha}^{-1} \mathrm{yr}^{-1}-$ this is considered to be sustainable, given the generally accepted soil formation rates (Verheijen et al., 2012). The remaining 24\% of the European land area, which has soil loss rates above $2 \mathrm{t} \mathrm{ha}^{-1} \mathrm{yr}^{-1}$, contributes to almost $87 \%$ of the total soil loss in Europe. Actual soil erosion rates for tilled, arable land in Europe are, on average, 3 to 40 times greater than the 
upper limit of tolerable soil erosion, accepting substantial spatio temporal variation (Podmanicky et al., 2011). At the field scale, monitoring of soil losses in surface runoff from a land levelled arable field in Norway showed variations from 0.09 to $3.0 \mathrm{t} \mathrm{ha}^{-1} \mathrm{yr}^{-1}$ (Bechmann, 2012). In Switzerland, the highest erosivity values are recorded from July to August and the lowest ones in the winter months (Meusburger et al., 2012).

Lithuanian climate is favourable for the occurrence of water erosion (Jankauskas, Jankauskiené, 2003; Kinderiene, Karcauskiene, 2012). Soil erosion is the most intensive factor of Lithuanian relief transformation, given that the estimated volume of all deposits re-deposited by erosion reaches 47.6 million $\mathrm{m}^{3}$ sediments per year. The depth of denudation reaches $\leq 0.5 \mathrm{~mm}^{-1} \mathrm{yr}^{-1}$ (Cesnulevicius, 2011). Soil erosion intensity in Lithuania depends mainly on tillage (mechanical) erosion, which has been identified as the main cause of accelerated soil erosion on arable slopes (Jankauskas, Fullen, 2006). Morgan (2006) has noted that the cause and extent of accelerated soil erosion are influenced by a number of factors in the first phase of sheet erosion when soil is removed by raindrop action (raindrop erosion). Rill erosion develops when any flow of water on an inclined soil surface causes small rills with the width and depth dimensions (Zachar, 1982). Runoff coefficient is as indicator of annual and seasonal runoff and land-use practices in rainfall recycling (Savenije, 1996). A very tight clay soil will also have a relatively high runoff coefficient, while a sandy soil should have more infiltration and a lower runoff coefficient (Marques et al., 2007).

Several studies have indicated that application of suitable cropping systems (crop rotations) significantly mitigates land degradation in sloping areas (Feiza et al., 2008; Cerdan et al., 2010). Vegetation cover reduces runoff and nutrient losses (Morgan, 2007). Soil erosion can be controlled through the plant cover. Thus, conservation of these vital resources needs to receive high priority to ensure the effective protection of managed and natural ecosystems (Zuazo et al., 2008). Different plant covers have different resistance to erosion and can afford soil protection differently (Račinskas, 1990). Mixtures of different plant functional types would improve soil conservation on slopes, by reducing both surface water erosion and shallow substrate mass movement (Fattet et al., 2011).

We hypothesize that long-term land-use/cover systems, where land has not been cultivated throughout the years, reduce the processes of soil erosion by water on hilly terrain.

The main aims of investigations were to assess changes and the extent of erosion process and distribution through the seasons over temporal dynamics scale and establish possibility for soil conservation on eroded hilly rolling landscape, based on land-use systems.

\section{Materials and methods}

Site and soil properties. The plot data represented measurements of surface runoff and soil loss under conditions in the hilly topography of Žemaičiai Upland, western part of Lithuania (Table 1). Three experiments were carried out in 1994-2012 at the Kaltinènai Research Station of the Lithuanian Institute of Agriculture (currently - Vėžaičiai Branch of the Lithuanian Research Centre for Agriculture and Forest). Soil of slope 9-11 ${ }^{\circ}$ was slightly eroded Eutric Retisol (loamic) (RT-eu.lo) and of slopes 7-8 and 7-9 - severely eroded Orthoeutric Regosol (loamic) (RG-oe.lo) (WRB, 2014). The data of soil erosion by water includes assessment of different land-use systems (rotation) scenarios over 18 years (1994-2012) period.

Table 1. Location and description of soil arable layer of the three long-term field experiments (1994)

\begin{tabular}{|c|c|c|c|}
\hline Slope and soil characteristic & Slope of $7-9^{\circ}$ & Slope of $9-11^{\circ}$ & Slope of $7-8^{\circ}$ \\
\hline \multirow{2}{*}{ Coordinates of experiments } & $55^{\circ} 3401^{\prime \prime} \mathrm{N}$ & $55^{\circ} 3502^{\prime \prime} \mathrm{N}$ & $55^{\circ} 3314^{\prime \prime} \mathrm{N}$ \\
\hline & $22^{\circ} 2920^{\prime \prime} \mathrm{E}$ & $22^{\circ} 2837^{\prime \prime} \mathrm{E}$ & $22^{\circ} 3336^{\prime \prime} \mathrm{E}$ \\
\hline Number of fields & 10 & 10 & 10 \\
\hline Plot length m & 80 & 65 & 50 \\
\hline Plot width $\mathrm{m}$ & 3.2 & 3.2 & 3.2 \\
\hline Ploughing layer thickness mm & 200 & 240 & 180 \\
\hline $\mathrm{P}_{2} \mathrm{O}_{5} \mathrm{mg} \mathrm{kg}^{-1}$ & 70 & 68 & 139 \\
\hline $\mathrm{K}_{2}^{2} \mathrm{O} \mathrm{mg} \mathrm{kg}^{-1}$ & 198 & 185 & 291 \\
\hline Soil organic matter $\%$ & 1.96 & 2.58 & 2.00 \\
\hline Soil $\mathrm{pH}_{(\mathrm{KCl}}$ & 6.2 & 6.8 & 6.5 \\
\hline \multicolumn{4}{|l|}{ Soil texture (Kachinsky method): } \\
\hline sand $(1-0.05 \mathrm{~mm})$ & 10 & 38 & 8 \\
\hline silt $(0.05-0.001 \mathrm{~mm})$ & 64.4 & 50 & 62 \\
\hline clay $(<0.001 \mathrm{~mm})$ & 25.6 & 12 & 30 \\
\hline Soil textural class (Fere triangle, FAO recommended method) & silt loam & silt loam & silty clay loam \\
\hline
\end{tabular}

Land-use systems and field measurements. Six land-use systems were compared over an 18-year period. One rotation period was 6-year long. Experimental design: 1 - field crop rotation (F), 2 - field crop rotation with the black fallow (FF), 3 - erosion-resisting graingrass crop rotation (GR), 4 - erosion-resisting grassgrain crop rotation (GS), 5 - not fertilized and not used grassland $(\mathrm{NG})$ and 6 - fertilized and mown grassland (FG). Crop rotation composition scheme is given below: 1 - the field crop rotation: winter rye (Secale cereale L.), potato (Solanum tuberosum L.), spring barley (Hordeum vulgare L.), spring barley + undercrop red clover (Trifolium pratense L.) + timothy (Phleum pratense L.) mixture, red clover + timothy mixture $1^{\text {st }}$ year of use, red clover + timothy mixture $2^{\text {nd }}$ year of use; 2 - field crop rotation with the black fallow: winter rye, potato, spring barley + undercrop (red clover + timothy mixture), red clover + timothy mixture, spring barley, black fallow; 3 - erosion-resisting grain-grass crop rotation: winter rye, spring barley, spring barley, spring barley + undercrop (red 
clover + timothy mixture), red clover + timothy mixture $1^{\text {st }}$ year of use, red clover + timothy mixture $2^{\text {nd }}$ year of use; 4 - erosion-resisting grass-grain crop rotation: winter rye, barley + undercrop cocksfoot (Dactylis glomerata L.) + fescue (Festuca rubra L.) mixture, cocksfoot + fescue mixture $1^{\text {st }}$ year of use, cocksfoot and fescue mixture $2^{\text {nd }}$ year of use, cocksfoot and fescue mixture $3^{\text {rd }}$ year of use, cocksfoot and fescue mixture $4^{\text {th }}$ year of use; 5 not fertilized and not used grassland formed from multicomponent mixture of perennial meadow plants; 6 fertilized and mown grassland (perennial meadow plant mixture of the same composition as in crop rotation 5).

Field plots for grain and potato growth were deeply ploughed in September. In spring, those fields were cultivated and harrowed and sown with plants (except for black fallow field).

Soil analysis. Representative soil samples $(0$ $20 \mathrm{~cm}$ depth) were taken from each field plot before field experiments. Soil $\mathrm{pH}_{\mathrm{KCL}}$ was determined in $1 \mathrm{M} \mathrm{KCl}$ soil sample extracts using a digital $\mathrm{pH}$-meter, mobile $\mathrm{P}_{2} \mathrm{O}_{5}$ and $\mathrm{K}_{2} \mathrm{O}$ using the $\mathrm{A}-\mathrm{L}$ method (available $\mathrm{P}$ and $\mathrm{K}$ were extracted with ammonium acetate-lactate solution, $\mathrm{pH} 3.7$, ratio 1:20). The volume of water runoff $\left(\mathrm{hl} \mathrm{ha}^{-1} \mathrm{yr}^{-1}\right)$ and soil loss $\left(\mathrm{Mg} \mathrm{ha}^{-1} \mathrm{yr}^{-1}\right)$ were observed on a regular basis, weekly during erosive rains in 10 experimental fields, in each experiment. Surface water runoff and soil loss from field plots was directed into soil and water collectors. Soil texture until 2000 in Lithuania was determined by the Kachinsky method according to the percentage of clay fraction $(<0.01)$. The new soil classification system involving application of the international GibssRozenbom methodology according to percentage of sand, silt and clay fractions in the graphical diagram, often called Fere triangle (FAO recommended method) has been used since 1999 (Mažvila et al., 2003).

Statistical analysis. Data of soil loss, runoff volume were processed using the ANOVA one-way analysis of variance, Duncan's multiple range test. Correlation and regression and paired regression data analyses were performed using STAT-ENG, the program SELEKCIJA (Tarakanovas, Raudonius, 2003). Statistical significance was evaluated at the $P \leq 0.05$ and $P \leq 0.01$ probability levels. Runoff coefficient $(\mathrm{Cr})$ is an important index of water recourses.

Annual $\mathrm{Cr}$ for an event at a point in the erosion plot was estimated by equation (Savenije, 1996):

$\mathrm{Cr}=$ runoff $/$ precipitation $(\mathrm{mm})$

Plant erodible resistance coefficient (Car) on slopes of average steepness and length (the range of variation 0-1.0) was calculated using the formula (Račinskas, 1990):

$$
\mathrm{Car}=\left(\mathrm{Z}_{\mathrm{a}}-\mathrm{Z}_{\mathrm{k}}\right) / \mathrm{Z}_{\mathrm{a}}
$$

where $Z^{a}$ is soil loss amount in bare soil $(\mathrm{Mg}$ $\left.\mathrm{ha}^{-1} \mathrm{yr}^{-1}\right), \mathrm{Z}_{\mathrm{k}}$ - soil loss amount with plant cover $\left(\mathrm{Mg} \mathrm{ha} \mathrm{h}^{-1}\right.$ $\left.\mathrm{yr}^{-1}\right)$.

Effectiveness of soil loss reduction was calculated as follows (Sutherland, 1998):

SLRE $(\%)=100 \times$ black fallow rotation SL $\left(\mathrm{Mg} \mathrm{ha}^{-1} \mathrm{yr}^{-1}\right)$ - a particular plant or group of plants $\mathrm{SL}\left(\mathrm{Mg} \mathrm{ha}^{-1} \mathrm{yr}^{-1}\right) /$ black fallow rotation soil loss $\mathrm{Mg} \mathrm{ha}^{-1}$ $\mathrm{yr}^{-1}$

where SLRE is effectiveness of soil loss reduction, $\mathrm{SL}$ - soil loss $\mathrm{Mg} \mathrm{ha}^{-1} \mathrm{yr}^{-1}$.

Topographical conditions. Monitoring study of erosion events was located in the hilly topography of the southern-central Žemaičiai Upland of western part of Lithuania. Soil was severely $\left(7-8^{\circ}, 7-9^{\circ}\right)$ and slightly $\left(9-11^{\circ}\right)$ eroded along the slope. Sheet and rill erosion forms prevailed in the field plots. Slopes of hills were concave - convex morphology form, south aspects. Soil erosion was mainly caused by tillage and rainfall under continuous intensive cropping.

Meteorological conditions. Precipitation is the most variable climate attribute. Average annual amount of precipitation in Lithuania during the 1981-2010 period was $695 \mathrm{~mm}$ (climate normal $(\mathrm{CN})-675 \mathrm{~mm})$. Most of the precipitation falls during the warm season (MayOctober) - $449 \mathrm{~mm}(\mathrm{CN}-445 \mathrm{~mm})$, and less during the cold season (November-March) - $246 \mathrm{~mm}$ (CN $230 \mathrm{~mm}$ ). The Lithuanian climate is favourable for the occurrence of water erosion. Mean annual precipitation amount at Laukuva Meteorological Station, Šilalè distr. was $812.5 \mathrm{~mm} \mathrm{yr}^{-1}$, according to the data from the past 45 years (Galvonaite et al., 2013). During the autumn and spring periods, when the rains are long-lasting but sparse, the erosion on soil surface is weaker, but the conditions for leaching are very favourable. In Nordic countries (Norway), the highest soil erosion risks to agricultural land mainly occurs in autumn through heavy rainfall, and in spring through heavy snowmelt (Øygarden et al., 2006, Ulen et al., 2012).

Data show, that higher than $900 \mathrm{~mm}$ annual precipitation amount compared with the multi-annual (1960-2011) average was in 1995, 1998, 2001, 2007 and 2010. Comparison of annual precipitation during the entire study period indicated that the rainiest years were: 2010 annual precipitation was $1016.3 \mathrm{~mm}$ (or $46.2 \%$ exceeded perennial average) and 2007 - annual precipitation was $961 \mathrm{~mm}$ (or $18.3 \%$ more than multi-annual average). Less amount of precipitation was observed in 2008 and $2009-786$ and $797.1 \mathrm{~mm}$, respectively. Assessment of study period's (18 years) meteorological conditions demonstrated that little rainfall occurred in February and March, with the exception of year 1995. Regular droughty weather, with low precipitation (on average $42 \mathrm{~mm}$ ) was in April (Fig. 1).

Analysis of annual meteorological data shows that less precipitation occurred in 1996-amount of annual precipitation was $488.4 \mathrm{~mm}$ (or only $60 \%$ of multi-annual amount of precipitation). Annual soil loss rate in this year in separate study locations was little. In 2003, 2005 and 2006 , the annual amount of precipitation was less than a quarter of the multi-annual average - over $600 \mathrm{~mm}$. In the following years of study erosion process was dependent on the amount and the intensity of torrential rainfall in the summer (mainly July) and autumn periods. Only in one (2006) of the three years with small amount of precipitation soil erosion almost did not occur. Soil loss due to water erosion in 2006 compared to 2003 and 2005 was 19-26 and 3-53 times lower. Exceptional, very dry weather conditions in April $(24 \mathrm{~mm})$ were observed in the $3^{\text {rd }}$ crop rotation period (2007-2012). Most abundant rains during the long-term experimental periods prevailed in the summer and autumn months. Therefore, erosion processes on bare soil (fallow) were the most severe at that time. Exceptionally abundant rainfall was in August (2010 - $179 \mathrm{~mm}$ and $2011-166.2 \mathrm{~mm})$.

Also notable abundance of precipitation was in July 1998, 2000, 2001, 2002, 2010, 2011 and 2012 and in winter periods $-1995,1998$ and $2008,1^{\text {st }}$ and $3^{\text {rd }}$ of the crop rotation period. Due to the rapid climate warming, annual, seasonal and monthly departures 


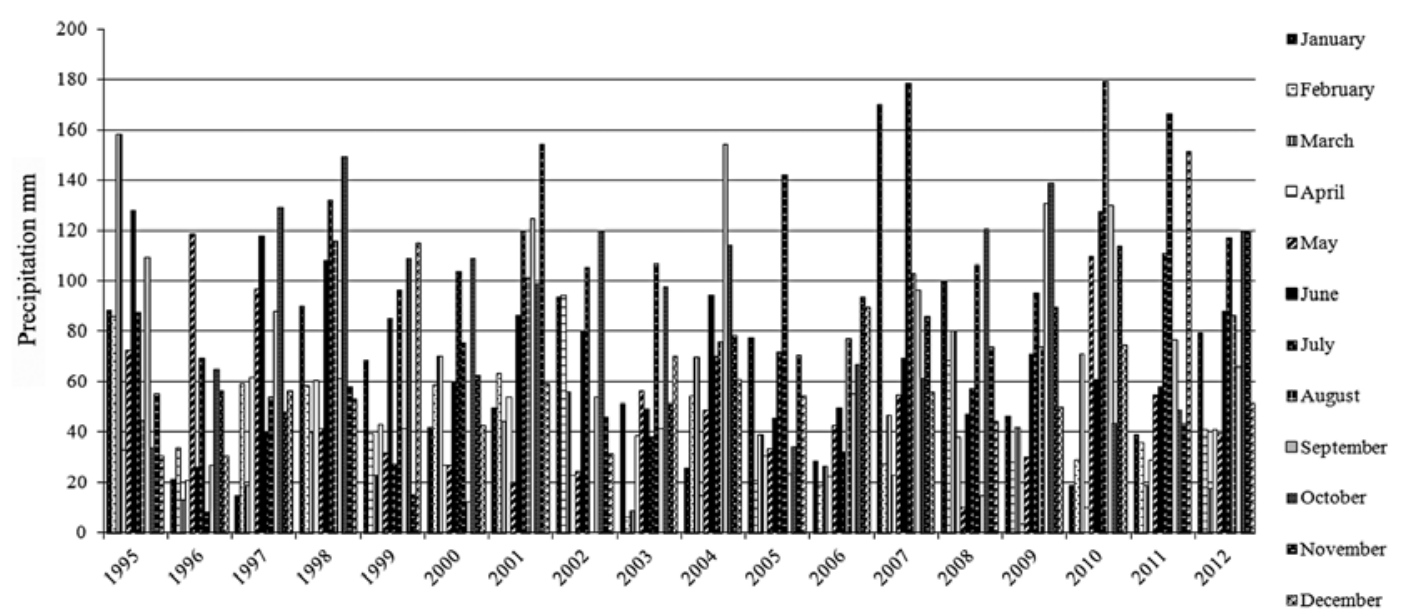

Figure 1. Mean monthly precipitation during the long-term study period (data from Laukuva Meteorological Station, Šilale distr.)

from climate normal $(\mathrm{CN})$ are observed with increasing frequency. Rainfall distribution throughout the year is not homogeneous, not even during one single day, particularly in summer, when sudden storms are usual (Marques et al., 2007).

In 1981-2010, annual average air temperature in Lithuania was $6.9^{\circ} \mathrm{C}\left(\mathrm{CN}-6.2^{\circ} \mathrm{C}\right)$. The warmest month was July with average temperature $17.9^{\circ} \mathrm{C}(\mathrm{CN}-$ $\left.16.7^{\circ} \mathrm{C}\right)$, and the coldest was January with $-3.2^{\circ} \mathrm{C}(\mathrm{CN}-$ $-5.1^{\circ} \mathrm{C}$ ) (Galvonaite et al., 2013). The average annual air temperature in experimental sites over $1^{\text {st }}$ crop rotation period (1995-2000) was $6.3^{\circ} \mathrm{C}$, over $2^{\text {nd }}(2001-2006)$ and over $3^{\text {rd }}(2007-2012)$ crop rotation period $-6.5^{\circ} \mathrm{C}$. The lowest for the entire period annual air temperature $\left(5^{\circ} \mathrm{C}\right)$ was in 1996 and 2012.

\section{Results and discussion}

Surface runoff volume. Climate warming processes $\left(0.7^{\circ} \mathrm{C}\right)$ in the last 30 years according to Galvonaite et al. (2013) and rising positive air temperatures even during the cold period (in December and January of 2007 the monthly air temperature was 0.7 and $1.9^{\circ} \mathrm{C}$, in February and March $2008-1.7$ and $1.5^{\circ} \mathrm{C}$, in November 2011 and $2012-3.6^{\circ} \mathrm{C}$ and $4.0^{\circ} \mathrm{C}$, respectively) induce water runoff and soil sediment transport processes in the snowmelt period. Elliott (2013) indicates that in Canada water runoff during the cold period for multiple snowmelt events was higher, and during the warm period - lower and highly dependent on soil. The average annual data of runoff volume shows that runoff was much higher on the slope of 7-8 $\left(464-756 \mathrm{hl} \mathrm{ha}^{-1} \mathrm{yr}^{-1}\right)$ and on slope of 7-9 (512-877 $\left.\mathrm{hl} \mathrm{ha}^{-1} \mathrm{yr}^{-1}\right)$, where in top layer of soil there were more silt and clay particles, than in soil of slope $9-11^{\circ}$. Due to more sand particles in soil, water infiltration was better on slope $9-11^{\circ}$ and runoff volume was 315-744 hl $\mathrm{ha}^{-1} \mathrm{yr}^{-1}$. This is also because soil contained more organic matter as cementing agents (Skøien, Børresen, 2012).

Comparing mean annual runoff rate results of the three slopes in relative values it was established that water runoff volume from FF system plots was higher of all land-use systems in all experimental sites. Annual runoff volume average in this system of the period 1995 2000 was $792.7 \mathrm{hl} \mathrm{ha}^{-1} \mathrm{yr}^{-1}$, of 2001-2006 - 499.4 hl $\mathrm{ha}^{-1} \mathrm{yr}^{-1}$, while of 2007-2012 - 550 hl ha-1 $\mathrm{yr}^{-1}$ (Fig. 2). Runoff volume in the $\mathrm{F}$ land-use system, compared with runoff volume in FF system, in the $1^{\text {st }}, 2^{\text {nd }}$ and $3^{\text {rd }}$ rotation periods was less $-10.3,8.5$ and $19.6 \%$, respectively. The data from 18 experimental years clearly show that runoff caused by rainfall in different years depended not only on the amount of precipitation, soil infiltration capacity, soil surface conditions, but also on vegetation type and slope covering with plants (Morgan, 2007). Runoff volume over $3^{\text {rd }}$ crop rotation compared with $1^{\text {st }}$ decreased from 430 to $162 \mathrm{hl} \mathrm{ha}^{-1} \mathrm{yr}^{-1}$ in NG and from 510 to $210 \mathrm{hl}$ $\mathrm{ha}^{-1} \mathrm{yr}^{-1}$ in FG systems, where naturally remaining plant residues prevented soil from runoff and helped water sink into deeper soil layers.

Runoff volume in long-term NG and FG landuse system fields, compared with that of $\mathrm{F}$, during the $1^{\text {st }}$ crop rotation period (1995-2000) was $39.0 \%$ and $28.2 \%$ less, during the $2^{\text {nd }}(2001-2007)-64.5 \%$ and $46.0 \%$, and during the $3^{\text {rd }}(2008-2012)-41.6 \%$ and $34.3 \%$. The lowest $(P<0.01)$ runoff volume was found in long-term NG and FG systems compared with that in F land-use system in $7-9^{\circ}, 7-8^{\circ}$ erosion experiment sites in $1^{\text {st }}-3^{\text {rd }}$ rotations. We attribute this to a fundamental difference in runoff generation and sediment transfer according to land cover type (Cerdan et al., 2010).

Moderate correlation was found between the amount of annual runoff volume and amount of annual precipitation ( $r=0.422-0.418, P>0.05, \mathrm{n}=18)$ using FG land-use system. Between the runoff volume and the amount of annual precipitation in the NG and FG systems there was weak correlation $(r=0.121, P>0.05, \mathrm{n}=18)$. Therefore in this situation grass vegetation was as barrier for the water runoff from the slope surface.

Relief affecting surface runoff factors were plant species, soil properties, and slope and catchment characteristics. A coefficient of runoff $(\mathrm{Cr})$ value as runoff indicator was not stable and depended on land-use system. During the $1^{\text {st }}, 2^{\text {nd }}$ and $3^{\text {rd }}$ crop rotation periods $\mathrm{Cr}$ was the highest in FF land-use system plots - 1.0, 0.69 and 0.63 , respectively. In erosion resisting GR system plots average $\mathrm{Cr}$ over all period was rather high -0.68 and in GS system fields -0.54 . The results revealed the high protective effects of grass on slopes. It was found that NG and FG systems reduced runoff coefficient to 0.36-0.43. In silt loam (slope of $7-9^{\circ}$ ) and silt clay loam (slope of $7-8^{\circ}$ ) soils runoff coefficient was the highest $0.53-0.86$ and $0.42-0.77$, respectively; while a silt loam soil (slope of $\left.9-11^{\circ}\right)$ had a lower runoff coefficient $(0.34-0.73)$. 


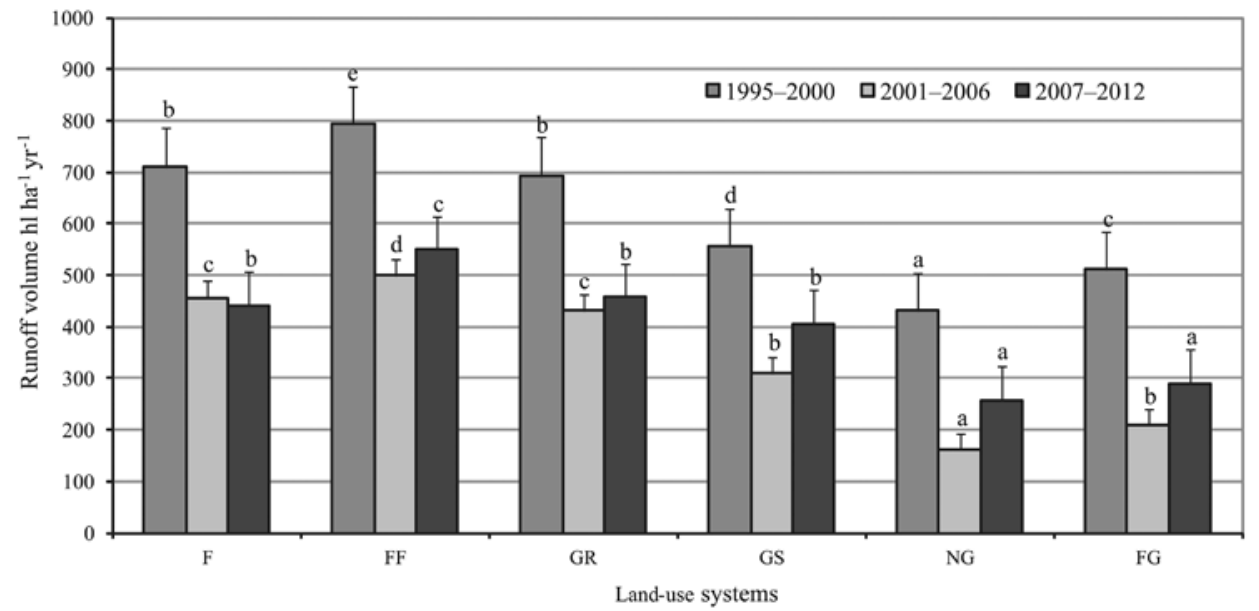

Note. Different symbols $(\mathrm{a}, \mathrm{b}, \mathrm{c})$ over columns represent significant differences among treatments at $p \leq 0.05$; land-use systems: $\mathrm{F}$ - field crop rotation, FF - field crop rotation with the black fallow, GR - erosion-resisting grain-grass crop rotation, GS - erosionresisting grass-grain crop rotation, $\mathrm{NG}$ - not fertilized and not used grassland, $\mathrm{FG}$ - fertilized and mown grassland.

Figure 2. Average of the annual runoff volume of the three experiments with different land-use systems over the three crop rotation periods

Soil (outwash) loss. Soil erosion rate results from $1^{\text {st }}(1995-2006)$ and $2^{\text {nd }}(2001-2007)$ crop rotation periods in the same experiments have been reported in Lithuanian and foreign scientific literature by Jankauskas and Jankauskiene $(2003 ;$ 2007). According to the authors, annual water erosion rates during long-term field experiments were: $5.4-17.0 \mathrm{Mg}^{-1}$ under winter rye, $18.0-62.8 \mathrm{Mg} \mathrm{ha}^{-1}$ under spring barley and 44.4-186.2 Mg $\mathrm{ha}^{-1}$ under potatoes. Other authors suggest that soil loss can vary in response to the topography and hillslope conditions (Feiza et al., 2008; Bechmann, 2012; Ulen et al., 2012) and rainfall intensity (Račinskas, 1990).

According to summarized study results, based on land-use systems, it was observed that the annual soil loss $\left(\mathrm{Mg} \mathrm{ha}^{-1} \mathrm{yr}^{-1}\right)$ of three erosion experiments over 18 years - during three crop rotation periods was the greatest of soil from FF system (Fig. 3). From F land-use system plot in the $1^{\text {st }}, 2^{\text {nd }}$ and $3^{\text {rd }}$ crop rotation periods loss of soil was 2, 3 and 23 times less, compared with FF land-use system. Even smaller soil losses were established on slop plots with erosion preventive GR (3.7 to 6.6 times) and especially with GS (7.1 to 23.9 times) land-use systems, compared with FF. However, soil losses from the study site plots occupied with multi-component mixture of perennial plants (NG and FG systems) were minimal and very similar $-0.1-0.01 \mathrm{Mg} \mathrm{ha}^{-1} \mathrm{yr}^{-1}$.

Results demonstrated that land-use systems must vary in response to rain intensity and slope conditions. The greatest annual soil outwash $13.9 \mathrm{Mg} \mathrm{ha}{ }^{-1} \mathrm{yr}^{-1}$ (moderate erosion) was established during the $3^{\text {rd }}$ crop rotation period (2007-2012), while it was 5.8\% lower during the $1^{\text {st }}$ and $32.9 \%$ during the $2^{\text {nd }}$ rotation. Extreme and intensive summer-autumn rainfall (2009 and 2012) stimulated erosion processes in the FF land-use system fields and losses of soil on slope of $9-11^{\circ}$, respectively, were 167.8 and $229 \mathrm{Mg} \mathrm{ha}^{-1} \mathrm{yr}^{-1}$. Such amount of soil losses according to Zachar (1982), are assessed as "very severe erosion". At the same time on 7-9 $9^{\circ}$ slope soil losses were respectively: 57.6 and $16.6 \mathrm{Mg} \mathrm{ha}^{-1} \mathrm{yr}^{-1}$ (severe erosion), while on $7-8^{\circ}$ slope -13.6 and $0.82 \mathrm{Mg}$ $\mathrm{ha}^{-1} \mathrm{yr}^{-1}$ (losses are assessed as from moderate to slight erosion). Račinskas (1990) also indicated that erosion risk is the highest from May to June, when the surface coverage by crops is small and high intensity rainfall



Note. Different symbols (a, b, c) over columns represent significant differences among treatments at $p \leq 0.05$; landuse systems: $\mathrm{F}$ - field crop rotation, FF - field crop rotation with the black fallow, GR - erosion-resisting grain-grass crop rotation, GS - erosion-resisting grass-grain crop rotation, NG not fertilized and not used grassland, FG - fertilized and mown grassland.

Figure 3. The mean annual soil loss due to water erosion as influenced by land-use systems over the three crop rotation periods (average data of three experiments)

may occur. The effect of slope conditions (inclination) and soil properties (soil texture, organic matter) on soil losses from investigated six crop systems was stronger on a bare soil in FF land-use system.

According to research data, lower soil loss (0.21-4.34 Mg ha-1 $\mathrm{yr}^{-1}$ ) compared with FF system was established when slopes were occupied by GR system plants. Sod-forming perennial plants in NG and FG, which were resistant to runoff, stopped soil loss regardless of location, steepness of the slope and soil texture. Several studies have indicated that application of suitable cropping systems (crop rotations) significantly mitigates land degradation in sloping areas (Morgan, 2007; Cerdan et al., 2010). By authors, vegetation cover on slopes reduces runoff and nutrient losses (Jankauskas, Jankauskienè, 2003). 
According to the data of long-term studies, mainly loss of topsoil was on slope of $9-11^{\circ}$ steepness, compared to other study sites in the FF land-use system (Fig. 4). In Sweden it was established that clay loam soil was more resistant to water erosion (Ulen et al., 2012). In the experiment carried out on slope of $7-9^{\circ}$, compared with experiment on slope of $9-11^{\circ}$, soil loss volume during the $1^{\text {st }}-3^{\text {rd }}$ crop rotation periods was $78.7-$ $80.8 \%$ lower. However, average annual soil loss volume

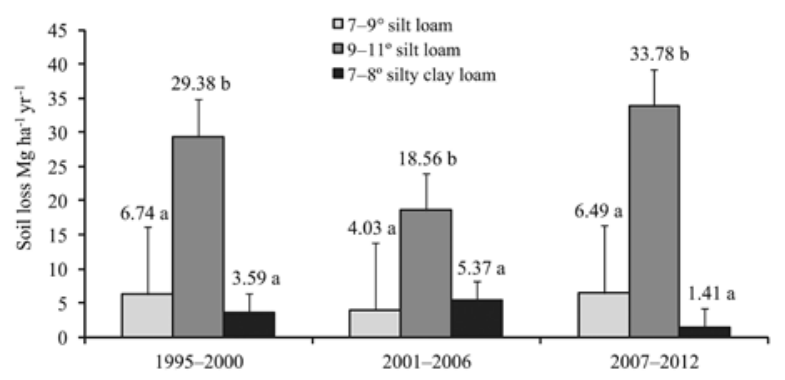

Note. Different symbols (a, b, c) over columns represent significant differences among treatments at $p \leq 0.05$.

Figure 4. The mean annual soil loss in field crop rotation with the black fallow (FF) land-use system plots on slopes of different steepness and soil texture over the three crop rotation periods in the F and FF systems and erosion-resisting GR and GS use systems was the highest in the $1^{\text {st }}$ crop rotation period during the research studies period. Soil erosion processes were encouraged by ploughing tillage used for potato, spring barley and winter rye growing also rainfall intensity and its abundance.

Minimum annual soil loss due to erosion during 18 years of the study, compared with experiments on other slopes, was established on $7-8^{\circ}$ slope with silty clay loam texture, in the $3^{\text {rd }}$ crop rotation. These losses (1.41 Mg ha-1 $\mathrm{yr}^{-1}$ ) were even considered to be tolerable. Effectiveness of soil loss reduction (SLRE) shows great seasonal variability on slopes in accordance with soil surface cover changes over the year due to abundant rainfall events, plant growth and development stages, land-use systems.

Bare soil in FF land-use system by Sutherland (1998) was not resistant to disturbance, and SLRE was equal to 0 . If in traditional $\mathrm{F}$ crop rotation SLRE during the $1^{\text {st }}$ period (1995-2000) was $52 \%$, and during the $3^{\text {rd }}$ period (2007-2012) - 96\%, while SLRE in the NG and FG land-use systems with sward cover from multiplecomponent mixture of meadow plants was $99-100 \%$ (Table 2).

Paired regression analyses during the 18year research period between plant (floral) erodible resistance coefficient (Car) and soil loss showed very

Table 2. Indicators of erosive stability of slope soil using different land-use systems over 18-year period

\begin{tabular}{|c|c|c|c|c|c|c|}
\hline \multirow[b]{2}{*}{$\begin{array}{l}\text { Land-use } \\
\text { system }\end{array}$} & \multicolumn{2}{|c|}{$1995-2000$} & \multicolumn{2}{|c|}{$2001-2006$} & \multicolumn{2}{|c|}{$2007-2012$} \\
\hline & $\begin{array}{c}\text { runoff } \\
\text { coefficient } \\
(\mathrm{Cr})\end{array}$ & $\begin{array}{c}\text { soil loss } \\
\text { reduction } \\
\text { effectiveness } \\
\text { (SLRE) } \%\end{array}$ & $\begin{array}{c}\text { runoff } \\
\text { coefficient } \\
(\mathrm{Cr})\end{array}$ & $\begin{array}{c}\text { soil loss } \\
\text { reduction } \\
\text { effectiveness } \\
(\mathrm{SLRE}) \%\end{array}$ & $\begin{array}{c}\text { runoff } \\
\text { coefficient } \\
(\mathrm{Cr})\end{array}$ & $\begin{array}{c}\text { soil loss } \\
\text { reduction } \\
\text { effectiveness } \\
\text { (SLRE) \% }\end{array}$ \\
\hline Field crop rotation $(\mathrm{F})$ & 0.94 & 52 & 0.62 & 65 & 0.51 & 96 \\
\hline $\begin{array}{l}\text { Field crop rotation with } \\
\text { the black fallow }(\mathrm{FF})\end{array}$ & 1.0 & 0 & 0.68 & 0 & 0.63 & 0 \\
\hline $\begin{array}{l}\text { Grain-grass crop } \\
\text { rotation }(\mathrm{GR})\end{array}$ & 0.92 & 72 & 0.58 & 69 & 0.53 & 85 \\
\hline $\begin{array}{l}\text { Grass-grain crop } \\
\text { rotation }(\mathrm{GS})\end{array}$ & 0.72 & 86 & 0.42 & 86 & 0.47 & 96 \\
\hline $\begin{array}{l}\text { Not fertilized and not } \\
\text { used grassland (NG) }\end{array}$ & 0.57 & 99 & 0.22 & 100 & 0.30 & 99 \\
\hline $\begin{array}{l}\text { Fertilized and mown } \\
\text { grassland (FG) }\end{array}$ & 0.67 & 99 & 0.28 & 100 & 0.34 & 99 \\
\hline
\end{tabular}

strong, negative, significant relationships $(r=-0.99$, $P<0.01, \mathrm{n}=18)$. Correlation analysis between Car and $\mathrm{Cr}$ coefficients showed moderate strength, significant and negative relationship $(r=-0.607, P<0.01, \mathrm{n}=18)$. Therefore, on the slopes of the hills by increasing soil erosion-preventive power with plants, in particular, decreased soil loss due to erosion caused by precipitation because of reduced surface runoff volumes.

The results in the Table 2 revealed the efficiency of soil loss reduction when applying NG and FG systems with formed vegetation cover of long term plants. Established runoff coefficient $(\mathrm{Cr})$ values as hydrology component were three times lower in 2001-2006 crop rotation period and twice in both 2007-2012 and 19952000 periods in NG land-use system. Runoff and soil loss reduction (SLRE 99-100\%) were negligible in field plots with plants (crop or grasses). In this regard, the GS system was superior to the GR land-use system.

\section{Conclusions}

1. Research data from the long-term (18 years) soil erosion studies on hillslopes of Western Lithuania showed that most numerous events of erosion processes - runoff and soil loss occurred in field crop rotation with the black fallow (FF land-use system), during extreme rains in the summer and autumn months.

2. Surface runoff volume strongly depended on rainfall characteristics, soil texture and land-use systems. On hillslopes of $7-9^{\circ}$ with silt loam and $7-8^{\circ}$ with silty clay loam soil texture, runoff volume was higher than that on hillslope $9-11^{\circ}$ with silt loam soil texture. The average annual runoff volume in a field crop rotation with the black fallow (FF land-use system) during 1995-2000 period was $792.7 \mathrm{hl} \mathrm{ha}^{-1} \mathrm{yr}^{-1}$, during 2001-2006 period $-499.4 \mathrm{hl} \mathrm{ha}^{-1} \mathrm{yr}^{-1}$ and during 2007-2012 - $550 \mathrm{hl} \mathrm{ha}^{-1}$ $\mathrm{yr}^{-1}$. Annual amounts of runoff volume were $36-54 \%$ 
less from not fertilized and not used grassland (NG) and fertilized and mown grassland (FG) land-use systems, compared with FF system.

3. During 18 years' research period (1995-2012) soil loss yield $\left(9.32-13.89 \mathrm{Mg} \mathrm{ha}^{-1} \mathrm{yr}^{-1}\right)$ in the FF landuse system plots depended on rainfall characteristics. In field crop rotation ( $\mathrm{F}$ land-use system), during the implementation of the $1^{\text {st }}, 2^{\text {nd }}$ and $3^{\text {rd }}$ rotations, soil loss was 2, 3 and 23 times lower, compared with FF landuse system. Erosion-resisting grain-grass (GR) and grass-grain (GS) land-use systems decreased soil loss compared with field crop rotation with the black fallow (FF) on average 5 and 15.5 times, respectively.

4. On the cultivated hillslopes over the long period of research, annual soil loss $(r=-0.99, P<0.01$, $\mathrm{n}=18)$ and the annual runoff volumes $(r=-0.607$, $P<0.01, \mathrm{n}=18)$ strongly reduced $\mathrm{NG}$ and FG landuse systems. Vegetation in agro-systems with meadow grasses ( $1^{\text {st }}$ and $2^{\text {nd }}$ year of use) significantly reduced the risk of soil loss from topsoil using also other (GS and GR) land-use systems.

5. Runoff and soil loss processes on hilly land (slopes of $7-8^{\circ}, 7-9^{\circ}$ and $9-11^{\circ}$ ) during torrential rains in warm period were controlled by vegetation cover. Environmentally-friendly and resistant to erosion processes was NG land-use system, formed from multicomponent meadow plant mixture. NG and FG systems stopped the loss of soil and thus increased the stability against erosion by water on the hilly topography of Lithuania, regardless of location, steepness of the slope and soil texture.

\section{Acknowledgements}

This study was conducted under the research programme "Productivity and sustainability of agricultural and forest soils" implemented by Lithuanian Research Centre for Agriculture and Forestry. The authors would like to thank all who were and are involved in the longterm experiment and to those, especially reviewers, who contributed to the improvement of the quality of the paper.

Received 22062016

Accepted 29092016

\section{References}

Bechmann M. 2012. Effect of tillage on sediment and phosphorus losses from a field and a catchment in south eastern Norway. Acta Agriculturae Scandinavica, Section B: Soil and Plant Science. Soil Erosion in the Nordic Countries (spec. iss.), 62 (2): 206-216

Boardman J., Poesen J. 2006. Soil erosion in Europe: major processes, causes and consequences. Boardman J., Poesen J. (eds.). Soil erosion in Europe. p. 479-488 http://dx.doi.org/10.1002/0470859202.ch36

Brunner A. C., Park S. J., Ruecker G. R., Vlek P. L. G. 2008 Erosion modelling approach to simulate the effect of old land management options on soil loss by considering catenary soil development and farmers perception. Land Degradation and Development. 19: 623-635 http://dx.doi.org/10.1002/ldr.865

Cerdan O., Govers G., Le Bissonnais Y., Van Oost K., Poesen J., Saby N., Gobin A., Vacca A., Quinton J., Auerswald K., Klik A., Kwaad F. J. P. M., Raclot D., Nonita I., Rejman J., Rousseva S., Muxart T., Roxo M. J., Dostal T. 2010. Rates and spatial variations of soil erosion in Europe: a study based on erosion plot data. Geomorphology, 122 (1-2): 167-177 http://dx.doi.org/10.1016/j.geomorph.2010.06.011

Cesnulevicius A. 2011. The morphometric structure of Lithuanian relief and its influence on erosion processes. Baltica. Geosciences in Lithuania: challenges and perspectives (spec. iss.), 24: 137-142 (in Lithuanian)

Elliott J.2013. Evaluating the potential contribution of vegetation as a nutrient source in snowmelt runoff. Canadian Journal of Soil Science, 93 (4): 435-443 http://dx.doi.org/10.4141/cjss2012-050

Evans R. 2010. Runoff and soil erosion in arable Britain: changes in perception and policy since 1945. Environmental Science and Policy, 13 (2): 141-149 http://dx.doi.org/10.1016/j.envsci.2010.01.001

Fattet M., Fu Y., Ghestem M., Ma W., Foulonneau M., Nespoulous J., Le Bissonnais Y., Stokes A. 2011. Effects of vegetation type on soil resistance to erosion: relationship between aggregate stability and shear strength. Catena, 87 (1): 60-69 http://dx.doi.org/10.1016/j.catena.2011.05.006

Feiza V., Feizienè D., Jankauskas B., Jankauskienè G. 2008. The impact of soil management on surface runoff, soil organic matter content and soil hydrological properties on the undulating landscape of Western Lithuania. ZemdirbysteAgriculture, 95 (1): 3-21

Galvonaite A. Kilpys J., Kitrienè Z., Valiukas D. 2013. Climate averages for Lithuania 1981-2010, p. 2-8 (in Lithuanian)

Jankauskas B., Fullen M. A. 2006. Soil erosion and conservation in Lithuania. Boardman J., Poesen J. (eds.). Soil erosion in Europe, p. 57-66

Jankauskas B., Jankauskienė G. 2003. Long-term erosion studies on the Žemaičiai Upland: 2. Intensity of water erosion. Zemdirbyste-Agriculture, 82 (2): 20-34 (in Lithuanian)

Jankauskas B., Jankauskienè G. 2007. Soil protecting land use system for hilly-undulating landscape. ZemdirbysteAgriculture, 94 (3): 146-161

Kinderiene I., Karcauskiene D. 2012. Effects of different crop rotations on soil erosion and nutrient losses under natural rainfall conditions in Western Lithuania. Acta Agriculturae Scandinavica, Section B: Soil and Plant Science, 62 (2): 199-205

Marques M J., Bienes R., Jiménez L., Pérez-Rodríguez R. 2007. Effect of vegetal cover on runoff and soil erosion under light intensity events. Rainfall simulation over USLE plots. Science of the Total Environment, 378 (1-2): 161-165 http://dx.doi.org/10.1016/j.scitotenv.2007.01.043

Mažvila J., Vaičys M., Motuzas A., Gustaitis K. 2003. Comparative studies of Lithuania's soil texture. Zemdirbyste-Agriculture, 83 (3): 4-18 (in Lithuanian)

Meusburger K., Steel A., Panagos P., Montanarella L., Alewell C. 2012. Spatial and temporal variability of rainfall erosivity factor for Switzerland. Hydrology and Earth System Science, 16: 167-177 http://dx.doi.org/10.5194/hess-16-167-2012

Morgan R. P. C. 2006. Soil erosion and conservation, 304 p.

Morgan R. P. C. 2007. Vegetative-based technologies for erosion control, in eco- and ground bio-engineering: the use of vegetation to improve slope stability. Developments in Plant and Soil Sciences, 103: 265-272 http://dx.doi.org/10.1007/978-1-4020-5593-5 26

Øygarden L., Lundekvam H., Børresen T., Arnoldussen A. 2006. Soil erosion in Norway. Boardman J., Poesen J. (eds.). Soil erosion in Europe, p. 3-15

Panagos P., Borrelli P., Poesen J., Ballabio C., Lugato E., Meusburger K., Montanarella L., Alewel C. 2015. The new assessment of soil loss by water erosion in Europe. Environmental Science and Policy, 54: 438-447 http://dx.doi.org/10.1016/j.envsci.2015.08.012

Podmanicky L., Balazs K., Belenyesi M., Centeri Cs., Kristof D., Kohlheb N. 2011. Modelling soil quality changes in Europe. An impact assessment of land use change on soil quality in Europe. Ecological Indicators, 11 (1): 4-15 
http://dx.doi.org/10.1016/j.ecolind.2009.08.002

Račinskas A. 1990. Soil erosion. Vilnius, Lithuania, 136 p. (in Lithuanian)

Savenije H. H. G. 1996. The runoff coefficient as the key to moisture recycling. Journal of Hydrology, $176(1-4): 219-225$ http://dx.doi.org/10.1016/0022-1694(95)02776-9

Skøien S., Børresen T. 2012. Effect of tillage and soil management on soil erosion in Norway. Acta Agriculturae Scandinavica, Section B: Soil and Plant Science. Soil Erosion in the Nordic Countries (spec. iss.), 62 (2): 191-198

Sutherland R. A. 1998. Rolled erosion control systems for hillslope surface protection: a critical review, synthesis and anglysis of available data. I. Background and formative years. Land Degradation and Development. 9: 465-486 http://dx.doi. org/10.1002/(SICI) 1099-145X(199811/12)9:6<465::AIDLDR311>3.0.CO;2-4

Tarakanovas P., Raudonius S. 2003. Agronominių tyrimų duomenų statistinè analizè taikant kompiuterines programas ANOVA, STAT, SPLIT-PLOT iš paketo SELEKCIJA ir IRRISTAT. Lithuanian University of Agriculture, $58 \mathrm{p}$. (in Lithuanian)

Ulen B., Bechmann M., Øygarden L., Kyllmar K. 2012. Soil erosion in Nordic countries - future challenges and research needs. Acta Agriculturae Scandinavica, Section B: Soil and Plant Science. Soil Erosion in the Nordic Countries (spec. iss.), 62 (2): 176-184

Verheijen F. G. A., Jones R. J. A., Rickson R. J., Smith C. J. 2009. Tolerable versus actual soil erosion rates in Europe. Earth-Science Reviews. 94: 23-38 http://dx.doi.org/10.1016/j.earscirev.2009.02.003

Verheijen F. G. A., Jones R. J. A., Rickson R. J., Smith C. J., Bastos A. C., Nunes J. P., Keizer J. J. 2012. Concise overview of European soil erosion research and evaluation. Acta Agriculturae Scandinavica, Section B: Soil and Plant Science. Soil Erosion in the Nordic Countries (spec. iss.), 62 (2): $185-190$

World reference base for soil resources. 2014. International soil classification system for naming soils and creating legends for soil maps. World Soil Resources Reports No. 106. FAO, Rome, $192 \mathrm{p}$.

Zachar D. 1982. Soil erosion. Developments in soil science. New York, USA, $547 \mathrm{p}$.

Zuazo V. H. D., Pleguezuelo C. R. R. 2008. Soil erosion and runoff prevention by plant covers. A review. Agronomy for Sustainable Development. 28 (1): 65-86 http://dx.doi.org/10.1051/agro:2007062

ISSN 1392-3196 / e-ISSN 2335-8947

Zemdirbyste-Agriculture, vol. 103, No. 4 (2016), p. 339-346

DOI 10.13080/z-a.2016.103.043

\title{
Dirvožemio erozijos procesų vertinimas taikant skirtingas žemės naudojimo sistemas kalvotame banguotame Vakarų Lietuvos reljefe
}

\author{
I. Kinderienė, D. Karčauskienè
}

Lietuvos agrarinių ir miškų mokslų centro Vèžaičių filialas

\section{Santrauka}

Tyrimo tikslas - įvertinti ilgalaikio skirtingų žemės naudojimo/dangos sistemų įtaką dirvožemio erozijos procesams kalvotame Žemaičių aukštumos reljefe. Analizuoti ilgalaikès stebėsenos (18 metų) duomenys iš trijų atskirų erozijos stacionaru su vandens ir dirvožemio sąnašu rinktuvais, įrengtų 7-8 $8^{\circ}, 7-9^{\circ}$ ir $9-11^{\circ}$ statumo šlaituose. Tirtos šešios žemėnaudos sistemos: lauko, lauko su juoduoju pūdymu, antierozinės javų bei žolių ir žolių bei javų, netręšiamo bei nenaudojamo ilgalaikio žolyno ir tręšiamo bei šienaujamo ilgalaikio žolyno.

Nustatyta, kad dirvožemio erozijos ir vandens nuotėkio apimtys šlaituose su ariama žeme labiausiai priklausẻ nuo atskirų pasėlių atsparumo erozijai, taikytos žemės dirbimo technologijos, šlaitų paviršiaus augalinės dangos, dirvožemio granuliometrinès sudèties ir kritulių pobūdžio. Vasaros ir rudens laikotarpiu liūtiniai krituliai buvo daugelio dirvožemio nuplovimo atvejų ir sąnašų kiekio - 167,8-229 $\mathrm{Mg} \mathrm{ha}^{-1}$, kuris apibūdinamas kaip labai stipri erozija, priežastis. Klimato atšilimo procesai $\left(0,7^{\circ} \mathrm{C}\right.$ per daugiau nei 30 metų) ir teigiama oro temperatūra net šaltojo periodo sąlygomis paskatino sniego tirpsmą ir vandens srauto nuotèki žemyn šlaito dirvos paviršiumi.

Apibendrinti ilgalaikių tyrimų rezultatai rodo, kad didžiausias vidutinis metinis kritulių vandens nuotekis $529 \mathrm{hl} \mathrm{ha}^{-1}$ ir vidutinis metinis dirvožemio netekimas $-11,6 \mathrm{Mg} \mathrm{ha}^{-1}$, buvo nustatyti iš augalais neužsèto pūdymo lauko rotacijoje su juoduoju pūdymu 9-11 $1^{\circ}$ šlaito, kurio dirvožemyje buvo daugiau smèlio frakcijos, palyginus su kitų stacionarų dirvožemio granuliometrine sudėtimi. Antierozinės javų bei žolių ir žolių bei javų žemėnaudos sistemos dirvožemio erozijos nuostolius sumažino atitinkamai 5 ir 15,5 karto, lyginant su lauko su juoduoju pūdymu sistema. Dirvožemio nuostolių sumažinimo veiksmingumas taikant netręšiamo bei nenaudojamo ir tręšiamo bei šienaujamo ilgalaikių žolynų žemėnaudos sistemas su suformuota ilgalaike žolyno danga buvo 99-100\%. Didelis žolinių augalų antierozinis atsparumas tinkamai pritaikant žemės naudojimo sistemas šlaituose itin sumažino dirvožemio nuostolius dèl vandeninès erozijos $(r=-0,99, P<0,01, \mathrm{n}=18)$ ir nutekejjusio šlaitais vandens kiekị $(r=-0,607, P<0,01, \mathrm{n}=18)$.

Reikšminiai žodžiai: dirvožemio nuostoliai, erozijai atsparios žemėnaudos sistemos, ilgalaikè stebėsena, šlaitai, vandens nuotèkis, Žemaičių aukštuma.

Please use the following format when citing the article:

Kinderiene I., Karčauskienė D. Assessment of soil erosion processes as influenced by different land-use systems on hilly rolling landscape of Western Lithuania. Zemdirbyste-Agriculture, 103 (4): 339-346 DOI 10.13080/za.2016.103.043 